\title{
Use of Canopeo for Estimating Green Coverage of Bermudagrass during Postdormancy Regrowth
}

\author{
Manoj Chhetri ${ }^{1}$ and Charles Fontanier ${ }^{2}$
}

AdDitionAL INDEX wORDs. colorants, Cynodon dactylon, digital image analysis, smartphone, spring green-up

Summary. Objective methods of estimating green coverage using digital image analysis have been used increasingly by turfgrass scientists. The objective of our research was to evaluate the effectiveness of Canopeo, a relatively new smartphone application, for estimating green coverage of bermudagrass (Cynodon dactylon) emerging from winter dormancy, with or without colorants. A field study was conducted on a research ' $U 3$ ' bermudagrass fairway in Stillwater, OK, during Spring 2019 and 2020. The experiment was conducted as a randomized complete block design with three colorant treatments: Endurant Fairway (FW), Endurant Perennial Ryegrass (PR), and an untreated control. Green coverage of the turfgrass canopy was determined weekly from mid-March to early May using a digital camera and Image J software, and a smartphone and the Canopeo application. Green coverage estimates from Canopeo correlated strongly $(r=0.91)$ with those from ImageJ when no colorants were applied. Correlation between Canopeo and ImageJ was diminished under plots treated with colorants. Canopeo is an effective tool for estimating green coverage of living turfgrasses, but additional calibration may be required for acceptable performance when evaluating greenness of colorant-treated turfgrasses.

A ccurate and objective characterization of the turfgrass canopy is a critical aspect of modern turfgrass research. Richardson et al. (2001) developed a method for analyzing digital images for percent green cover using commercial image analysis software. The same laboratory also developed methods to quantify turfgrass color, and has since released a dedicated software platform for turfgrass image analysis (Karcher and Richardson, 2003; Karcher et al., 2017). Use of image analysis to estimate green coverage of a turfgrass canopy has since been widely adopted for use in cultivar evaluation, drought

Received for publication 24 Aug. 2021. Accepted for publication 30 Sept. 2021

Published online 19 November 2021

${ }^{1}$ Department of Horticulture and Natural Resources, Kansas State University, Manhattan, KS 66502

${ }^{2}$ Department of Horticulture and Landscape Architecture, Oklahoma State University, Stillwater, OK 74078-6027

This work was supported in part by the U.S. Department of Agriculture, National Institute of Food and Agriculture, Hatch project OKL03039.

C.F. is the corresponding author. E-mail: charles. fontanier@okstate.edu.

This is an open access article distributed under the CC BY-NC-ND license (https://creativecommons. org/licenses/by-nc-nd/4.0/).

https://doi.org/10.21273/HORTTECH04938-21 response, freeze tolerance, disease severity, and divot recovery (Karcher and Richardson, 2013; Karcher et al., 2008; Patton and Reicher, 2007; Sykes et al., 2017; Williams et al., 2011).

Smartphone applications such as the FieldScout GreenIndex + Turf App (Spectrum Technologies, Aurora, IL) have also been used to detect the stress response of warm-season turfgrasses and potentially have greater appeal to nonresearchers (Xiang et al., 2017). A similar but less established smartphone application is Canopeo (Patrignani and Ochsner, 2015), which is freely available and operates on either Android (Google, Mountain View, CA) or iOS (Apple, Cupertino, CA) devices. The images are captured with a smartphone camera and are analyzed immediately to determine the percent green cover in real time. Canopeo has been used in various crops to quantify canopy cover (Shepherd et al., 2018), herbicide injury (Abreu et al., 2019), and disease severity (Yellareddygari and Gudmestad, 2017). In comparison with conventional turfgrass image analysis methods and other smartphone applications, Canopeo has the potential to provide a free and highly mobile approach to quantifying turfgrass green coverage.

The objective of our research was to determine the suitability of the Canopeo application for measuring green coverage of bermudagrass (Cynodon dactylon), with or without colorants, during postdormancy regrowth.

\section{Materials and methods}

A field study was conducted on an established ' $U 3$ ' bermudagrass at the Oklahoma Turfgrass Research Center in Stillwater, OK, in 2019 (year 1) and 2020 (year 2). Plots were mowed at 0.5 inch up to three times per week when actively growing. The study area received $3 \mathrm{lb} / 1000 \mathrm{ft}^{2}$ nitrogen from urea $(46 \mathrm{~N}-0 \mathrm{P}-0 \mathrm{~K})$ in three split applications during the growing season. The field was irrigated with an in-ground sprinkler system as needed to avoid visible drought stress.

Each experimental plot was $3 \times 8 \mathrm{ft}$ and assigned one of the three turfgrass colorant treatments: 1) Endurant FW (Geoponics Corp., Naples, FL), 2) Endurant PR (Geoponics Corp.), and 3 ) an untreated control. Colorants were all applied at a rate of $2.5 \mathrm{gal} /$ acre using a carbon dioxide-pressurized boom sprayer equipped with a banding nozzle (TeeJet AI9505E; Spraying Systems Co., Wheaton, IL) and calibrated to deliver $40 \mathrm{gal} / \mathrm{acre}$. Turfgrass colorants were applied on 12 Feb. 2019 (year 1) and 26 Mar. 2020 (year 2). Treatments were arranged in a randomized complete block design with six and four replicates in years 1 and 2 , respectively.

Data were collected weekly starting 20 Mar. in year 1 and 26 Mar. in year 2 until plots had fully greened up. One image was captured per plot using a digital camera (Powershot Gl6; Canon, Melville, NY) mounted

\begin{tabular}{llll}
\hline $\begin{array}{l}\text { Units } \\
\begin{array}{l}\text { To convert U.S. to SI, } \\
\text { multiply by }\end{array}\end{array}$ & U.S. unit & SI unit & $\begin{array}{l}\text { To convert SI to U.S., } \\
\text { multiply by }\end{array}$ \\
\hline 0.3048 & $\mathrm{ft}$ & $\mathrm{m}$ & 3.2808 \\
9.3540 & $\mathrm{gal} / \mathrm{acre}$ & $\mathrm{L} \cdot \mathrm{ha}^{-1}$ & 0.1069 \\
2.54 & inch $(\mathrm{es})$ & $\mathrm{cm}$ & 0.3937 \\
48.8243 & $\mathrm{lb} / 1000 \mathrm{ft}^{2}$ & $\mathrm{~kg} \cdot \mathrm{ha}^{-1}$ & 0.0205
\end{tabular}

Hortlechnology $\cdot$ December $202131(6)$ 


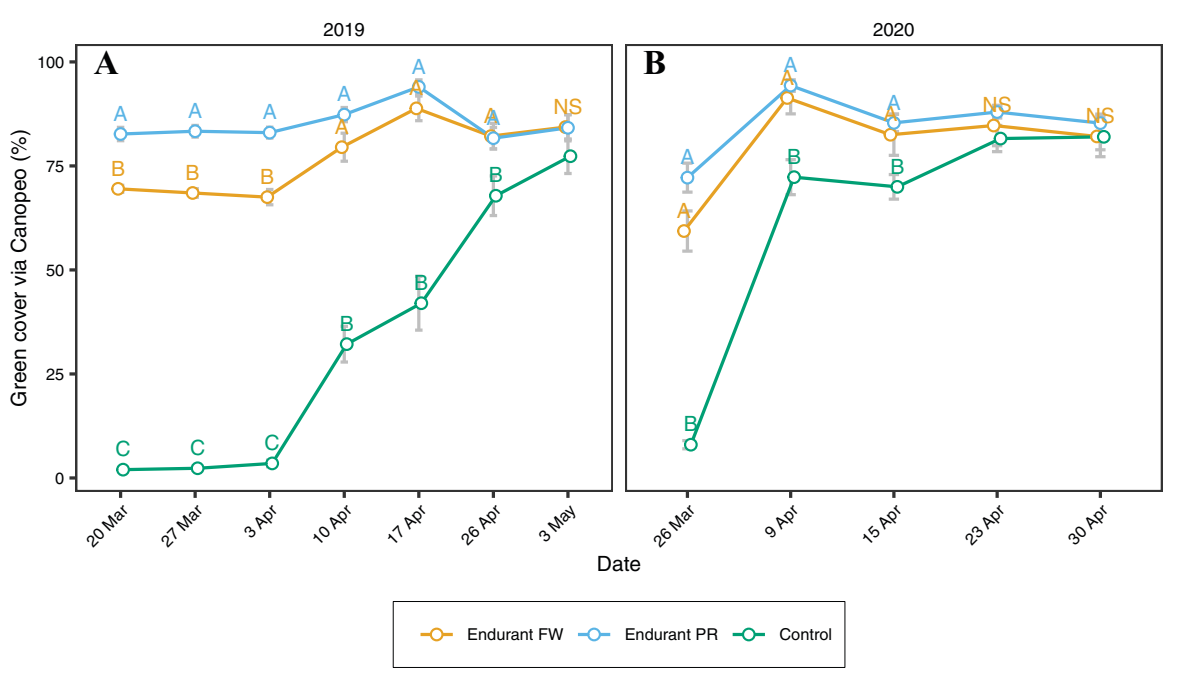

Fig. 1. Percent green cover measured using the Canopeo smartphone application (Patrignani and Ochsner, 2015) in (A) 2019 and (B) 2020 as affected by three turfgrass colorant treatments Endurant Fairway [Endurant FW (Geoponics Corp., Naples, FL)], Endurant Perennial Ryegrass [Endurant PR (Geoponics Corp.)], and a control on bermudagrass emerging from dormancy. Error bars represent \pm 1 SE of the mean. On each measurement date, means labeled with the same letter are not statistically different, and NS indicates no differences among treatments as tested using Tukey's honestly significant difference test at $\alpha \mathbf{~} \mathbf{0 . 0 5}$.

on the top of a standard light box. Images were then subjected to analysis with a free Java image-processing program [ImageJ, version $1.50 \mathrm{~b}$ (Rasband, 1997)] to determine

percent green cover (PGCJ) using a hue threshold of 40 to 125 . One image for each plot was also obtained independently using the built-in camera of a smartphone
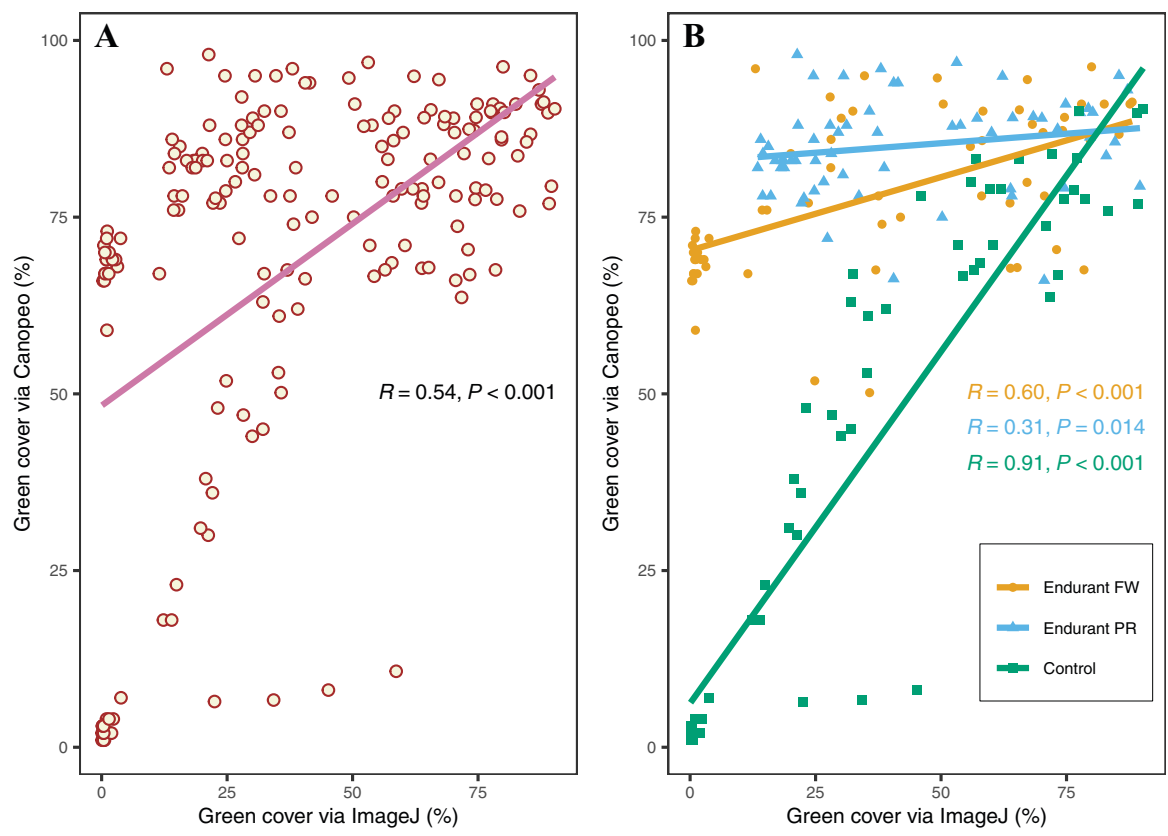

Fig. 2. Scatterplots of percent green cover estimated using the Canopeo smartphone application (Patrignani and Ochsner, 2015) vs. image analysis software [ImageJ (Rasband, 1997)]. Data were (A) analyzed across the three colorant treatments Endurant Fairway [Endurant FW (Geoponics Corp., Naples, FL)], Endurant Perennial Ryegrass [Endurant PR (Geoponics Corp.)], and a control for the global model, and (B) analyzed within each level of treatment.
(iPhone X, Apple) held $2 \mathrm{ft}$ above the turfgrass canopy, resulting in an $18-\times$ 24-inch image capture area. Images from the smartphone were then analyzed for percent green cover (PGCX) using the Canopeo application with a threshold setting of 1.03 , which had been determined previously to provide accurate estimates of live turfgrass green coverage. The data were subjected to repeated-measures analysis of variance in $\mathrm{R}$ using the lmer function in the lme4 package (Bates et al., 2015). Different variance-covariance structures were investigated to build the model, and the appropriate repeated-measures model was selected based on the log likelihood ratio test. Treatment means were separated using Tukey's honestly significant difference test at $P \leq 0.05$. Spearman's rank correlation test was conducted to test the relationship between the turfgrass coverage estimates at $\alpha=0.05$ using the cor function in $\mathrm{R}$.

\section{Results and discussion}

In each year of the study, the main effect of colorants $(P<0.0001$ in years 1 and 2 ) and interaction effect of colorants by measurement date $(P$ $<0.0001$ in years 1 and 2 ) on percent green cover using the Canopeo application were significant. Canopeo was able to generate wide variation among treatments for percent green cover immediately after application, such that Endurant PR > Endurant FW > control (Fig. 1). Similar differences in the performance of colorant products have been reported in previous studies and are influenced by their formulation and application method (Briscoe et al., 2010; Pinnix et al., 2018).

The moderate correlation $(r=0.54$, $P<0.001)$ between PGCX and PGCJ when pooling across both years and all treatments suggests that use of Canopeo to determine percent green cover can be a relatively inconsistent replacement for conventional digital image analysis methods (Fig. 2). Specifically, the relationship between green cover estimates can be skewed by the presence of a colorant (Pinnix et al., 2018). Endurant FW resulted in a moderately strong correlation $(r=0.60, P<0.001)$, whereas Endurant PR resulted in a weakly significant correlation $(r=0.31, P=0.014)$. The settings used for both methods were typical of what is commonly used for live green turfgrass (as shown by the good 
correlation for untreated plots). Use of an image analysis method may require novel calibration for useful evaluation of certain colorants. Nevertheless, the evidence of strong correlation in untreated turfgrass suggests Canopeo and conventional image analysis methods agree closely when measuring the coverage of live turfgrasses. Furthermore, as a free and ready to use application, Canopeo has the potential for use in both research and industry applications when instantaneous quantification of turfgrass green coverage is desired.

\section{Literature cited}

Abreu, L.F., A.C. Rocateli, M.R. Manuchehri, D.B. Arnall, and J.A. Antonangelo. 2019. Assessing glyphosate injury and forage bermudagrass regrowth using Canopeo. Amer. Soc. Agron., Crop Sci. Soc. Amer., Soil Sci. Soc. Amer. Intl. Annu. Mtg., Paper 119769 (abstr.). 30 Sept. 2021. <https://scisoc.confex. com/scisoc/2019am/meetingapp.cgi/ Paper/119769>.

Bates, D., R. Kliegl, S. Vasishth, and H. Baayen. 2015. Parsimonious mixed models. ArXiv:1506.04967 [Stat]. 30 Sept. 2021. <https://arxiv.org/abs/ 1506.04967>.

Briscoe, K., G. Miller, and S. Brinton. 2010. Evaluation of green turf colorants as an alternative to overseeding on putting greens. Appl. Turfgrass Sci. 7(1):1-8, https://doi.org/10.1094/ATS-20100326-02-RS.

Karcher, D.E., C.J. Purcell, M.D. Richardson, L.C. Purcell, and K.W. Hignight. 2017. A new Java program to rapidly quantify several turfgrass parameters from digital images. Amer. Soc.
Agron., Crop Sci. Soc. Amer., Soil Sci. Soc. Amer. Intl. Ann. Mtg. 2017:109313. (abstr.) 30 Sept. 2021. <https://scisoc. confex.com/crops/2017am/webprogram/ Paper109313.html>.

Karcher, D.E. and M.D. Richardson. 2003. Quantifying turfgrass color using digital image analysis. Crop Sci. 43(3):943-951, https://doi.org/10.2135/cropsci2003. 9430.

Karcher, D.E. and M.D. Richardson. 2013. Digital image analysis in turfgrass research, p. 1133-1149. In: J.C. Stier, B.P. Horgan, and S.A. Bonos (eds.). Turfgrass: Biology, use, and management. Agron. Monogr. 56. Amer. Soc. Agron., Crop Sci. Soc. Amer., Soil Sci. Soc. Amer. Madison, WI, https://doi.org/10.2134/ agronmonogr56.c29.

Karcher, D.E., M.D. Richardson, K. Hignight, and D. Rush. 2008. Drought tolerance of tall fescue populations selected for high root/shoot ratios and summer survival. Crop Sci. 48(2):771-777, https://doi.org/ 10.2135/cropsci2007.05.0272.

Patrignani, A. and T.E. Ochsner. 2015. Canopeo: A powerful new tool for measuring fractional green canopy cover. Agron. J. 107(6):2312-2320, https:// doi.org/10.2134/agronj15.0150.

Patton, A.J. and Z.J. Reicher. 2007. Zoysiagrass species and genotypes differ in their winter injury and freeze tolerance. Crop Sci. 47(4):1619-1627, https://doi.org/10.2135/cropsci2006. 11.0737 .

Pinnix, G.D., G.L. Miller, D.C. Bowman, and G.L. Grabow. 2018. Color, transfer, and application parameters of turfgrass colorants. Agron. J. 110(1):66-76, https:// doi.org/10.2134/agronj2017.03.0164.
Rasband, W.S. 1997. ImageJ. U.S. National Institutes of Health, Bethesda, MD.

Richardson, M.D., D.E. Karcher, and L.C. Purcell. 2001. Quantifying turfgrass cover using digital image analysis. Crop Sci. 4l(6):1884-1888, https://doi.org/ 10.2135/cropsci2001.1884.

Shepherd, M.J., L.E. Lindsey, and A.J. Lindsey. 2018. Soybean canopy cover measured with Canopeo compared with light interception. Agr. Environ. Lett. 3(1):180031, https://doi.org/10.2134/ ael2018.06.0031.

Sykes, V.R., B.J. Horvath, S.E. Warnke, S.D. Askew, A.B. Baudoin, and J.M. Goatley. 2017. Comparing digital and visual evaluations for accuracy and precision in estimating tall fescue brown patch severity. Crop Sci. 57(6):3303-3309, https://doi.org/10.2135/cropsci2016. 08.0699 .

Williams, B.T., J.K. Kruse, J.B. Unruh, and J.B. Sartain. 2011. An enhanced method of tracking divot recovery in turfgrass. Crop Sci. 51(5):2194-2198, https://doi.org/10.2135/cropsci2010. 11.0647

Xiang, M., J.Q. Moss, D.L. Martin, K. Su, B.L. Dunn, and Y. Wu. 2017. Evaluating the salinity tolerance of clonaltype bermudagrass cultivars and an experimental selection. HortScience 52:185-191, https://doi.org/10.21273/ HORTSCI10773-16.

Yellareddygari, S.K.R. and N.C. Gudmestad. 2017. Bland-Altman comparison of two methods for assessing severity of Verticillium wilt of potato. Crop Prot. 101:68-75, https://doi.org/10.1016/j. cropro.2017.07.019. 